\title{
INDENIZAÇÃO À PROPRIETÁRIOS DE IMÓVEIS LOCALIZADOS EM APPS
}

\author{
INDEMNIFICATION TO PROPRIETORS OF PROPERTIES LOCATED IN APPS
}

\author{
Gilberto Passos de Freitas ${ }^{1}$ \\ Marcus Filipe Freitas Coelho ${ }^{2}$
}

\section{Resumo}

Este artigo tem por escopo analisar a possibilidade de indenização aos proprietários particulares de imóveis situados em Áreas de Preservação Permanente (APPs) afetados em sua potencialidade econômica diante de tais limitações administrativas impostas pela Administração Pública. Desde a edição do Código Florestal de 1965 (Lei $\mathrm{n}^{\circ}$ 4.771/65), foram estabelecidas diversas limitações ao direito de propriedade no que se refere ao uso e exploração do solo, em especial as Áreas de Preservação Permanente. Nesse sentido, há quem defenda que em razão de o proprietário não ter o direito de explorar tais áreas em virtude da localização do imóvel, não haveria que se falar em indenização, sob pena de enriquecimento ilícito, vedado no ordenamento jurídico brasileiro. Por outro lado, há quem sustente que apesar de a limitação não implicar na perda da propriedade, acaba impedindo o uso da área e, consequentemente, acarreta a desvalorização econômica do bem e a exploração da área, o que configuraria o direito constitucional de desapropriação indenizada.

Palavras-chave: Indenização. Desapropriação. Área de preservação permanente.

\begin{abstract}
The purpose of this article is to analyze the possibility of indemnification to private landowners located in Permanent Preservation Areas affected by their economic potential in the face of such administrative limitations imposed by the Public Administration. Since the 1965 Forest Code (Law no. 4,771/65), several limitations to the right to property were established with regard to land use and exploitation, especially the Permanent Preservation Areas. In this sense, there are those who argue that because the owner does not have the right to exploit such areas because of the location of the property, it would not be necessary to speak about

1 Doutor em Direito pela Pontifícia Universidade Católica de São Paulo. Desembargador aposentado do Tribunal de Justiça do Estado de São Paulo. Membro do Conselho Superior de Meio Ambiente e Sustentabilidade da Associação dos Registradores Imobiliários de São Paulo. Foi Corregedor Geral da Justiça do TJSP (2006/2007). E- mail: gpassosfreitas@uol.com.br

2 Advogado. Aluno do Programa de Pós-Graduação Stricto Sensu em Direito da Universidade Católica de Santos. E-mail: marcus.filipe92@gmail.com
\end{abstract}


compensation, under penalty of illicit enrichment, prohibited in the Brazilian legal system. On the other hand, there are those who maintain that although the limitation does not imply the loss of property, it ends up impeding the use of the area and, consequently, entails the economic devaluation of the property and the exploration of the area, which would configure the constitutional right to expropriation indemnified.

Keywords: Indemnification. Expropriation. Permanent preservation area.

\begin{abstract}
"A propriedade é um dos temas mais vulcânicos da história dos povos. Em seu nome fizeram-se revoluções para defender o direito de propriedade, para limitá-lo ou extingui-lo. O conteúdo do termo alterou-se no decorrer do tempo. Antes, no direito romano, falava-se em propriedade plena, o que permitia o gozo, o uso e a fruição do bem sem qualquer limitação. Posteriormente, sob o influxo dos socialistas e da doutrina da destinação universal dos bens, elaborada por Leão III, a propriedade passou a contar com limitações, exigindo-se, no seu uso, a preservação de sua função social." (LEMBO, 2007 p. 199-200)
\end{abstract}

\title{
INTRODUÇÃO
}

A propriedade não pode mais ser encarada com o absolutismo liberal que outrora já Ihe foi aplicada. A Constituição de 1988 passou a determinar que deve a propriedade cumprir sua função social (art. $5^{\circ}$, inciso XXIII).

Por sua vez, o $\S 1^{\circ}$ do art. 1.228 do Código Civil também dispõe que:

o direito de propriedade deve ser exercido em consonância com as suas finalidades econômicas e sociais e de modo que sejam preservados, de conformidade com o estabelecido em lei especial, a flora, a fauna, as belezas naturais, o equilíbrio ecológico e o patrimônio histórico e artístico, bem como evitada a poluição do ar e das águas.

O novo quadro alterou a concepção do direito de propriedade, que adquiriu um caráter social, e se tornou um direito-dever condicionado à função social, aí incluída a função socioambiental. 
Elevada à condição de princípio constitucional e de direito fundamental, a função social da propriedade implica em profunda alteração no conteúdo do direito de propriedade ( SOARES e PADILHA, 2009, p. 15)

Sob este prisma, passou a ser garantia fundamental a propriedade entendida no contexto do interesse público, não podendo se sobrepor ao interesse da coletividade, notadamente em sua exploração econômica.

Em consequência, ao proprietário é vedado o exercício de determinadas faculdades, devendo, sob a perspectiva da solidariedade, adequar 0 seu comportamento às determinações legais protetivas da coletividade e do meio ambiente.

Assim, visando tutelar o meio ambiente, o ordenamento jurídico prevê a existência de Áreas de Preservação Permanente (APPs), as quais, em razão da proteção conferida pelo legislador, não se admite a exploração do solo e/ou a supressão da cobertura vegetal.

O instituto concretiza o princípio da função ecológica da propriedade, vinculando inúmeros deveres de proteção ambiental ao exercício e fruição do direito pelo seu titular (SARLET e FENSTERSEIFER, 2014, p. 109).

Assim, conquanto as APPs não impliquem a perda da propriedade, acarretam a abstenção do próprio uso, e geram, muitas vezes, perda do valor econômico do bem.

Nesse cenário, questiona-se acerca do direito à indenização aos proprietários ou possuidores de terras localizadas em APPs que são atingidos pelas limitações administrativas, cujos imóveis venham a ser afetados em sua potencialidade econômica.

\section{1. ÁREAS DE PRESERVAÇÃo PERMANENTE}

\subsection{Conceito}


As Áreas de Preservação Permanente (APPs) são espaços territoriais especialmente protegidos de acordo com o disposto no inciso III, $\S 1^{\circ}$, do art. 225 da Constituição Federal, in verbis:

Art. 225. Todos têm direito ao meio ambiente ecologicamente equilibrado, bem de uso comum do povo e essencial à sadia qualidade de vida, impondo-se ao Poder Público e à coletividade o dever de defendê-lo e preservá-lo para as presentes e futuras gerações.

$\S 1 \stackrel{0}{\circ}$. Para assegurar a efetividade desse direito, incumbe ao Poder Público:

[...]

III - definir, em todas as unidades da Federação, espaços territoriais e seus componentes a serem especialmente protegidos, sendo a alteração e a supressão permitidas somente através de lei, vedada qualquer utilização que comprometa a integridade dos atributos que justifiquem sua proteção;

O instituto da APP que já era previsto no primeiro Código Florestal de 1934, passou por longo processo de aperfeiçoamento na vigência da Lei $n^{0}$ 4.771/65, persistindo sua obrigatoriedade no diploma vigente.

Assim, o novo Código Florestal, instituído pela Lei Federal nำ12.651/12, e posteriormente alterado pela Lei $n \times 12.727 / 12$, traz um detalhamento das Áreas de Preservação Permanente, além de definir outros espaços de uso limitado.

O art. 3ํ, inc. II, da Lei no 12.651/12 define Área de Preservação Permanente nos seguintes termos:

Art. 3․ Para os efeitos desta Lei, entende-se por:

[...]

II - Área de Preservação Permanente - APP: área protegida, coberta ou não por vegetação nativa, com a função ambiental de preservar os recursos hídricos, a paisagem, a estabilidade geológica e a biodiversidade, facilitar o fluxo gênico de fauna e flora, proteger o solo e assegurar o bem-estar das populações humanas;

Sua criação objetiva, em síntese, a proteção de fragilidades ambientais. De acordo com Paulo de Bessa Antunes (2005, p. 558), a APP é o "principal diploma legal brasileiro voltado para a proteção legal das florestas". 
As Áreas de Preservação Permanente não têm apenas a função de preservar a vegetação ou a biodiversidade, mas possuem uma função ambiental muito mais abrangente. Nas palavras de Wigold Bertoldo Schaffer et al (2011, p. 9), as APPs são voltadas, em última instância, "a proteger espaços de relevante importância para a conservação da qualidade ambiental como a estabilidade geológica, a proteção do solo e assim assegurar o bem estar das populações humanas".

Assim, o objeto de tutela do Código Florestal são as florestas existentes no território nacional e as demais formas de vegetação, reconhecidas de utilidade às terras que revestem.

Além disso, conforme prevê o art. 9º, inc. $\mathrm{VI}^{3}$, da Lei no 6.938/81, a criação de espaços territoriais especialmente protegidos pelo Poder Público federal, estadual e municipal, tais como áreas de proteção ambiental, de relevante interesse ecológico e reservas extrativistas são instrumentos da Política Nacional do Meio Ambiente.

O que motiva a atribuição de regime diferenciado a estas áreas é a localização em que se encontram e as funções ecológicas que desempenham.

\subsection{Modalidades}

O Código Florestal prevê duas modalidades de Áreas de Preservação Permanente: aquelas previstas no art. $4^{a}$, criadas por força da lei (ope legis), estando protegidas pelo simples fato de existirem materialmente; e aquelas previstas no art. 6ํㅡㄹ instituídas por ato do poder público, ou seja, que dependem da expedição de um ato administrativo específico do Prefeito, do Governador ou do Presidente da República para adquirirem o status de áreas protegidas.

\footnotetext{
${ }^{3}$ Art. 9o. São instrumentos da Política Nacional do Meio Ambiente:

$[\ldots]$

VI - a criação de espaços territoriais especialmente protegidos pelo Poder Público federal, estadual e municipal, tais como áreas de proteção ambiental, de relevante interesse ecológico e reservas extrativistas; [...]
} 
As áreas definidas no art. 4 o são em função de sua localização, aplicandose tanto à zona rural quanto à urbana, independentemente da adoção de alguma providência de demarcação pela Administração Pública.

Art. 4ํ․ Considera-se Área de Preservação Permanente, em zonas rurais ou urbanas, para os efeitos desta Lei:

I - as faixas marginais de qualquer curso d'água natural perene e intermitente, excluídos os efêmeros, desde a borda da calha do leito regular [...];

II - as áreas no entorno dos lagos e lagoas naturais [...];

III - as áreas no entorno dos reservatórios d'água artificiais, decorrentes de barramento ou represamento de cursos d'água naturais, na faixa definida na licença ambiental do empreendimento; IV - as áreas no entorno das nascentes e dos olhos d'água perenes, qualquer que seja sua situação topográfica, no raio mínimo de 50 (cinquenta) metros;

$\mathrm{V}$ - as encostas ou partes destas com declividade superior a $45^{\circ}$, equivalente a $100 \%$ (cem por cento) na linha de maior declive;

$\mathrm{VI}$ - as restingas, como fixadoras de dunas ou estabilizadoras de mangues;

VII - os manguezais, em toda a sua extensão;

VIII - as bordas dos tabuleiros ou chapadas, até a linha de ruptura do relevo, em faixa nunca inferior a 100 (cem) metros em projeções horizontais;

IX - no topo de morros, montes, montanhas e serras, com altura mínima de 100 (cem) metros e inclinação média maior que $25^{\circ}$, as áreas delimitadas a partir da curva de nível correspondente a 2/3 (dois terços) da altura mínima da elevação sempre em relação à base, sendo esta definida pelo plano horizontal determinado por planície ou espelho d'água adjacente ou, nos relevos ondulados, pela cota do ponto de sela mais próximo da elevação;

$X$ - as áreas em altitude superior a 1.800 (mil e oitocentos) metros, qualquer que seja a vegetação;

$X I$ - em veredas, a faixa marginal, em projeção horizontal, com largura mínima de 50 (cinquenta) metros, a partir do espaço permanentemente brejoso e encharcado.

$[\ldots]$

Por sua vez, as áreas definidas no art. 6º são caracterizadas em razão de sua destinação, cabendo ao chefe do Poder Executivo declará-las de interesse social:

Art. 6․ Consideram-se, ainda, de preservação permanente, quando declaradas de interesse social por ato do Chefe do Poder Executivo, as áreas cobertas com florestas ou outras formas de vegetação destinadas a uma ou mais das seguintes finalidades: 
I - conter a erosão do solo e mitigar riscos de enchentes e deslizamentos de terra e de rocha;

II - proteger as restingas ou veredas;

III - proteger várzeas;

IV - abrigar exemplares da fauna ou da flora ameaçados de extinção;

$\mathrm{V}$ - proteger sítios de excepcional beleza ou de valor científico, cultural ou histórico;

$\mathrm{VI}$ - formar faixas de proteção ao longo de rodovias e ferrovias;

VII - assegurar condições de bem-estar público;

VIII - auxiliar a defesa do território nacional, a critério das autoridades militares.

IX - proteger áreas úmidas, especialmente as de importância internacional.

De acordo com Paulo Affonso Leme Machado, as APPs possuem seis características:

a) é uma área e não mais uma floresta (no Código Florestal de 1965, com a redação original, tratava-se de "floresta de preservação permanente"). A área pode ou não estar coberta por vegetação nativa, podendo ser coberta por vegetação exótica; b) não é uma área qualquer, mas uma "área protegida", proibindo-se "qualquer utilização que comprometa a integridade dos atributos que justifiquem sua proteção" (Art. 225, $\S 1^{\circ}$, III, da Constituição); c) a área é protegida de forma "permanente", isto é, não é uma proteção descontínua, temporária ou com interrupções; d) é uma área protegida, com funções ambientais específicas e diferenciadas, apontadas na Lei $n$. 12.651/2012: funções ambientais de preservação abrangendo os recursos hídricos, a paisagem, a estabilidade geológica e a biodiversidade; função de facilitar o fluxo gênico de fauna e de flora; proteção do solo, evitando a sua erosão e conservando a sua fertilidade; finalidade de assegurar o bem-estar das populações humanas; e) a vegetação situada em Área de Preservação Permanente deverá ser mantida pelo proprietário da área, possuidor ou ocupante a qualquer título, pessoa física ou jurídica, de direito público ou privado; e f) a supressão indevida da vegetação na APP obriga o proprietário da área, o possuidor ou o ocupante, a qualquer título, a recompor a vegetação, e essa obrigação tem natureza real. Essa obrigação transmite se ao sucessor, em caso de transferência da propriedade ou da posse do imóvel rural. (MACHADO, 2013, p. 16)

A manutenção das APPs possibilita a valorização da paisagem e do patrimônio natural e construído (de valor ecológico, histórico, cultural, paisagístico e turístico..(MINISTÉRIO DO MEIO AMBIENTE, [s.a.]). 
A Lei no $12.651 / 12$ não admite o uso da propriedade sem o respeito das regras atinentes à proteção das Áreas de Preservação Permanente. Todos os imóveis, independentemente da destinação outrora dada às terras, estão sujeitos à obrigação de mantê-las.

\section{LIMITAÇÕES ADMINISTRATIVAS}

Conforme expressamente previsto no artigo $170^{4}$ da Constituição Federal, um dos fundamentos da ordem econômica brasileira é a livre iniciativa, mas para sua concretização, é preciso observar, dentre outros princípios, a função social da propriedade (inciso III) e a defesa do meio ambiente (inciso VI).

É transparente a intenção do legislador constituinte em preservar as florestas e formas de vegetação, razão pela qual, a própria atividade econômica tem como pressuposto a proteção ambiental.

Não há dúvidas de que o ordenamento jurídico condiciona a exploração econômica da propriedade mediante a observância de um meio ambiente ecologicamente equilibrado, preservado os seus recursos naturais, razão pela qual a implantação das APPs, conquanto limite a exploração econômica do bem pelo particular, compatibiliza-se com o interesse coletivo.

Nesse sentido, as APPs são uma forma de limitação administrativa, definida por Hely Lopes Meirelles como sendo "toda imposição geral, gratuita, unilateral e de ordem pública condicionadora do exercício de direitos ou de atividades particulares às exigências do bem-estar social”.(MEIRELLES, 2001, p. 568)

Na definição de Maria Sylvia Zanella Di Pietro, limitações administrativas são "medidas de caráter geral, previstas em lei com fundamento no poder de polícia do

4 Art. 170. A ordem econômica, fundada na valorização do trabalho humano e na livre iniciativa, tem por fim assegurar a todos existência digna, conforme os ditames da justiça social, observados os seguintes princípios:

[...]

III - função social da propriedade;

[...]

VI - defesa do meio ambiente [...]; 
Estado, gerando para os proprietários obrigações positivas ou negativas, com o fim de condicionar o exercício do direito de propriedade ao bem-estar social". (DI PIETRO, 2006, p. 145)

O fundamento do poder de polícia, que lastreia principiologicamente a limitação administrativa, é a supremacia do interesse público.

Assim, levando-se em consideração que a grande característica da limitação administrativa é a sua generalidade, sendo imposta em favor do interesse coletivo, em regra não há que se falar em indenização ao proprietário atingido pelo gravame imposto pelo Poder Público.

Desse modo, posiciona-se José dos Santos Carvalho Filho:

Sendo imposições de ordem geral, as limitações administrativas não rendem ensejo à indenização em favor dos proprietários. As normas genéricas, obviamente, não visam a uma determinada restrição nesta ou naquela propriedade, abrangem quantidade indeterminada de propriedades. Desse modo, podem contrariar interesses dos proprietários, mas nunca direitos subjetivos. Por outro lado, não há prejuízos individualizados, mas sacrifícios gerais a que se devem obrigar os membros da coletividade em favor desta. (CARVALHO FILHO, 2012, p. 791)

Como se viu, a limitação administrativa possui caráter genérico, limitando o exercício de direitos individuais, mas não impedindo o regular uso da propriedade; trata-se apenas de adequar o direito de propriedade à sua função social, especificamente no tocante à preservação do meio ambiente. Por tais razões, em princípio, não haveria que se falar em indenização.

Por outro lado, no caso de desapropriação de um imóvel, observados os procedimentos previstos em lei, a indenização será de plano devida, pois nessa hipótese, não é o exercício do direito de propriedade que está sendo atingido como ocorre no caso das limitações administrativas, mas sim o próprio direito de propriedade que está sendo afetado. 
A Constituição Federal, em seu art. 5º, inc. XXIVª , apresenta os requisitos ou condições autorizativas da desapropriação, quais sejam: necessidade pública, utilidade pública ou interesse social, pagamento de indenização prévia, justa e em dinheiro.

Nesse sentido, manifesta-se a doutrina de José Carlos de Moraes Salles:

Desapropriação é instituto de direito público, que se consubstancia em procedimento pelo qual o Poder Público (União, Estadosmembros, Territórios, Distrito Federal e Municípios), as autarquias ou as entidades delegadas autorizadas por lei ou contrato, ocorrendo caso de necessidade ou de utilidade pública, ou ainda, de interesse social, retiram determinado bem de pessoa física ou jurídica, mediante justa indenização, que, em regra, será prévia e em dinheiro, podendo ser paga, entretanto, em títulos da dívida pública ou da dívida agrária, com cláusula de preservação de seu valor real, nos casos de inadequado aproveitamento do solo urbano ou de Reforma Agrária, observados os prazos de resgate estabelecidos nas normas constitucionais respectivas. (SALLES, 2006, p.88)

Tendo em vista que a própria Constituição Federal garante a indenização prévia e justa em casos de desapropriação, é evidente que o proprietário deverá ser indenizado em tal hipótese, ainda que o imóvel esteja localizado em uma Área de Preservação Permanente.

Nesse caso, a indenização consiste no pagamento feito ao proprietário de imóvel que teve parte ou a totalidade de sua área desapropriada pelo Poder Público. O valor da indenização é definido de acordo com o tamanho da área desapropriada e seus acessórios.

Assim sendo, o presente artigo realizou uma análise casuística dos julgados nos Tribunais Superiores exclusivamente quanto às limitações administrativas instituídas pelo Poder Público em que o particular teve seu imóvel afetado em sua potencialidade econômica em razão, excluindo-se da análise os casos decorrentes

\footnotetext{
${ }^{5}$ Art. 5ㅇ, inc. XXIV - a lei estabelecerá o procedimento para desapropriação por necessidade ou utilidade pública, ou por interesse social, mediante justa e prévia indenização em dinheiro, ressalvados os casos previstos nesta Constituição; [...]
} 
de desapropriação, pois nessas hipóteses a indenização decorre do texto expresso de lei.

Nesse sentido, de acordo com o levantamento jurisprudencial realizado, foi possível constatar que o Poder Judiciário não é pacífico quanto ao assunto, sendo que em determinados casos afasta por completo os pleitos de indenização, ao passo que em outros casos, concede a indenização.

\section{ARGUMENTOS A FAVOR DA INDENIZAÇÃO AOS PROPRIETÁRIOS DE IMÓVEIS SITUADOS EM ÁREAS DE PRESERVAÇÃO PERMANENTE}

Há quem entenda que o Estado, ao impor limitações administrativas aos particulares proprietários de terras localizadas em Áreas de Preservação Permanente, com o objetivo de tutelar o meio ambiente, tem também a obrigação de pagamento de indenização compensatória, quando a atividade pública, decorrente do exercício de atribuições em tema de direito florestal, impedir ou afetar a válida exploração econômica do imóvel.

Nesse sentido, elucida Lívia Nogueira Ramos, ao comentar sobre a intervenção do Estado na propriedade que venha a impossibilitar o uso e gozo de um bem, retirando-Ihe o conteúdo econômico: "O que não pode o poder público é fazer com que um particular custeie, isoladamente, a instituição de um benefício coletivo, com o detrimento de seu patrimônio - que lhe é garantido pela ordem constitucional."(RAMOS, [s.a.], [s.p.])

Nessa senda, Juliano Heinen, em seu artigo "Limitações administrativas e o conteúdo econômico da propriedade", também posiciona-se favoravelmente pela indenização aos proprietários que, em razão de um ato administrativo, tiveram inviabilizada a livre disposição do imóvel, não conseguindo dar ao bem a destinação a que ele se propõe: 
Assim, limitações administrativas são aceitas de forma plena, sem indenização qualquer, desde que o ônus gerado seja razoável e não inviabilize o espectro econômico de um bem, ou seja, não sobeje a limitação regular de um direito individual. Essa seria uma atuação normal e permitida. Caso exista o transpasse desses limites, ou seja, haja uma sujeição especial do bem que subtraia ou prejudique a função a que ele se destina, existe um dever de proteção. No caso, gera-se uma indenização justa, nos mesmos moldes da desapropriação. (HEINE, 2012, p. 172-173)

Interessante trazer a advertência de Hely Lopes Meirelles, o qual defende que a limitação administrativa não pode promover o aniquilamento da propriedade, isto é, a total impossibilidade de sua adequada utilização econômica, pois nesse caso "deixará de ser limitação para ser interdição de uso da propriedade e, nesse caso, o Poder Público ficará obrigado a indenizar a restrição que aniquilou o direito dominial e suprimiu o valor econômico do bem”. (MEIRELLES, 2001, p. 612-613)

Assim, fica evidente, que para os defensores dessa corrente o Estado indeniza o esvaziamento econômico.

O Agravo Regimental do Recurso Extraordinário n² 290.950, julgado em 2014 pelo Supremo Tribunal Federal, assentou a tese de que os proprietários de imóveis localizados em áreas referentes à cobertura vegetal e à preservação permanente devem ser indenizados.

A ementa transcrita a seguir bem ilustra o posicionamento da Corte Superior:

Agravo regimental no recurso extraordinário. Administrativo. Desapropriação. Área de preservação permanente. Cobertura vegetal. Plena indenizabilidade das matas e revestimentos florestais que recobrem áreas dominiais privadas, objeto de apossamento estatal ou sujeitas às restricõos administrativas ao direito de propriedade. Mantida a decisão com que se reconheceu que 0 acórdão atacado pelo recurso extraordinário violou precedentes da Corte. Precedentes. Agravo regimental não provido. ${ }^{6}$ (grifou-se e destacou-se)

6 STF - Agravo Regimental no Recurso Extraordinário oㅡ 290.950-SP, Relator: Ministro DIAS TOFFOLI, Data de Julgamento: 04/11/2014, PRIMEIRA TURMA, Data de Publicação: DJe 02/02/2015. 
Na oportunidade, o parecer do Ministério Público Federal, subscrito pela Subprocuradora-Geral da República Dra. Sandra Cureau, foi no mesmo sentido do julgamento proferido pelo STF:

É pacífica a jurisprudência dessa Egrégia Suprema Corte, porém, no sentido de que as áreas de preservação permanente, embora sujeitas a limitações administrativas, não anulam o valor econômico das matas, comportando integral compensação financeira nas hipóteses de desapropriação pelo ente estatal. ${ }^{7}$

Esse não é o primeiro caso julgado pelo STF sobre o assunto em questão. Em 1995, o Ministro Celso de Mello, ao relatar o Recurso Extraordinário nํ 134.297$\mathrm{SP}$, posicionou-se pelo reconhecimento da garantia de compensação financeira, sempre que o Estado, mediante atividade que the seja juridicamente imputável, atingir o direito de propriedade em seu conteúdo econômico em razão de limitação administrativa de cunho ambiental.

Nesse caso em específico, importante mencionar que o imóvel particular afetado pela ação do Poder Público estava localizado em uma reserva florestal e não em uma Área de Preservação Permanente, objeto do estudo em questão.

Contudo, ainda assim, tal decisão reveste-se de extrema importância para a análise que aqui se faz, uma vez que os argumentos expendidos naquela ocasião, especialmente o da necessidade de se compensar financeiramente o proprietário em razão da limitação administrativa, foram utilizados recentemente pelo STF $^{8}$ para decidir lides que envolvem indenizações aos proprietários de imóveis situados em APPs.

$\mathrm{Na}$ hipótese, o Recurso Extraordinário no 134.297-SP foi interposto pelo Estado de São Paulo contra acórdão proferido pelo Tribunal de Justiça Paulista que condenou o Estado a indenizar os proprietários de imóveis rurais afetados em sua vertente econômica, por ato do Poder Público Estadual que criou a Estação Ecológica da Juréia-Itatins.

\section{Ibdem.}

8 Vide Agravo Regimental do Recurso Extraordinário n² 290.950, de relatoria do Ministro Dias Toffoli. 
Ao chegar no Supremo Tribunal Federal, os Ministros chancelaram o acórdão originário do TJSP por unanimidade de votos. O Relator do caso, Ministro Celso de Mello, defendeu que a jurisprudência da Corte, em sucessivos pronunciamentos, "firmou orientação no sentido de que é dever do Poder Público indenizar o proprietário sempre a limitação administrativa afetar a possibilidade de exploração racional do imóvel por seu proprietário".

No caso, o esvaziamento do conteúdo econômico da propriedade restou comprovado, sobretudo diante do impedimento da execução de um projeto de cultura de cacau que era obtido com o aproveitamento dos recursos naturais existentes na área.

Assim, o Ministro ressaltou o posicionamento do TJSP nessa matéria, ao transcrever trecho do acórdão proferido pelo Tribunal Paulista: "Não se nega ao Estado o direito de constituir reservas florestais em seu território. Deve-se negar, todavia, o poder de constituí-las gratuitamente, à custa da propriedade particular de alguns proprietários".

A ementa do julgado em referência não deixa dúvidas quanto ao posicionamento da Suprema Corte:

RECURSO EXTRAORDINÁRIO - ESTAÇÃO ECOLÓGICA RESERVA FLORESTAL NA SERRA DO MAR - PATRIMÔNIO NACIONAL (CF, ART. 225, PAR.4.) - LIMITAÇÃO ADMINISTRATIVA QUE AFETA O CONTEÚDO ECONÔMICO DO DIREITO DE PROPRIEDADE - DIREITO DO PROPRIETÁRIO À INDENIZAÇÃO DEVER ESTATAL DE RESSARCIR OS PREJUÍZOS DE ORDEM PATRIMONIAL SOFRIDOS PELO PARTICULAR - RE NÃO CONHECIDO. - Incumbe ao Poder Público o dever constitucional de proteger a flora e de adotar as necessárias medidas que visem a coibir práticas lesivas ao equilíbrio ambiental. Esse encargo, contudo, não exonera o Estado da obrigacãa de indenizar os proprietários cujos imóveis venham a ser afetados, em sua potencialidade econômica, pelas limitacões impostas pela Administracão Pública. - A proteção jurídica dispensada as coberturas vegetais que revestem as propriedades imobiliárias não impede que o dominus venha a promover, dentro dos limites autorizados pelo Código Florestal, o adequado e racional aproveitamento econômico das árvores nelas existentes. A jurisprudência do Supremo Tribunal Federal e dos Tribunais em geral, tendo presente a garantia constitucional que protege o 
direito de propriedade, firmou-se no sentido de proclamar a plena indenizabilidade das matas e revestimentos florestais que recobrem áreas dominiais privadas objeto de apossamento estatal ou sujeitas a restricões administrativas impostas pelo Poder Público. Precedentes. - A circunstância de o Estado dispor de competência para criar reservas florestais não lhe confere, só por si - considerando-se os princípios que tutelam, em nosso sistema normativo, o direito de propriedade -, a prerrogativa de subtrair-se ao pagamento de indenizacão compensatória ao particular, quando a atividade pública, decorrente do exercício de atribuicões em tema de direito florestal, impedir ou afetar a válida exploracão econômica do imóvel por seu proprietário. - $A$ norma inscrita no ART.225, PAR.4., da Constituição deve ser interpretada de modo harmonioso com o sistema jurídico consagrado pelo ordenamento fundamental, notadamente com a cláusula que, proclamada pelo art. 5., XXII, da Carta Politica, garante e assegura o direito de propriedade em todas as suas projeções, inclusive aquela concernente a compensação financeira devida pelo Poder Público ao proprietário atingido por atos imputáveis a atividade estatal. $\mathrm{O}$ preceito consubstanciado no ART.225, PAR. 4., da Carta da Republica, além de não haver convertido em bens públicos os imóveis particulares abrangidos pelas florestas e pelas matas nele referidas (Mata Atlântica, Serra do Mar, Floresta Amazônica brasileira), também não impede a utilização, pelos próprios particulares, dos recursos naturais existentes naquelas áreas que estejam sujeitas ao domínio privado, desde que observadas as prescrições legais e respeitadas as condições necessárias a preservação ambiental. - A ordem constitucional dispensa tutela efetiva ao direito de propriedade (CF/88, art. 5., XXII). Essa protecão outorgada pela Lei Fundamental da República estendese, na abrangência normativa de sua incidência tutelar, ao reconhecimento, em favor do dominus, da garantia de compensacão financeira, sempre que o Estado, mediante atividade que lhe seja juridicamente imputável, atingir o direito de propriedade em seu conteúdo econômico, ainda que o imóvel particular afetado pela ação do Poder Público esteja localizado em qualquer das áreas referidas no art. 225, PAR. 4., da Constituição. - Direito ao meio ambiente ecologicamente equilibrado: a consagração constitucional de um típico direito de terceira geração (CF, art. 225, caput). ${ }^{9}$ (grifou-se e destacou-se)

Assim, para os defensores dessa corrente, entende-se que os imóveis insertos em Áreas de Preservação Permanente deverão ser indenizados de forma

9 STF - Recurso Extraordinário no 134.297-SP, Relator: Ministro CELSO DE MELLO, Data de Julgamento: 02/09/1995, PRIMEIRA TURMA, Data de Publicação: DJ 22/09/1995. 
plena, não existindo motivo jurídico para que haja a exclusão desses danos do cômputo da indenização.

Conquanto seja de índole comum o direito à preservação da integralidade ambiental, não se pode impor apenas aos proprietários de imóveis localizadas em tais áreas - que venham a sofrer as consequências derivadas das limitações administrativas incidentes sobre os seus imóveis - os ônus concernentes à concretização, pelo Estado, de seu dever jurídico-social de velar pela conservação, em benefício de todos, de um meio ambiente ecologicamente equilibrado.

\section{ARGUMENTOS CONTRA A INDENIZAÇÃO AOS PROPRIETÁRIOS DE IMÓVEIS SITUADOS EM ÁREAS DE PRESERVAÇÃO PERMANENTE}

Por outro lado, há quem defenda não ser possível a concessão de indenização nas hipóteses de imóveis situados em Áreas de Preservação Permanente, sob o argumento de que em razão da característica da área jamais seria impossível a sua exploração econômica pelo particular.

Nas palavras de Nagib Slaib Filho, "O meio ambiente é considerado bem de uso comum do povo, o que exclui [o meio ambiente] do rol dos bens que possam ser utilizados economicamente de forma privada, isto é, de serem apropriados, no seu uso, pelo indivíduo particular". (SLAIB FILHO, 1989, p. 307)

Sob esse prisma, isto está a significar que a neutralidade jurídico-patrimonial das Áreas de Preservação Permanente impediria de maneira incontornável - pelas restrições erga omnes sobre elas incidentes - que o proprietário, a qualquer título, possa delas usufruir explorando-as economicamente.

Como consequência, tal corrente sustenta que o pagamento de indenização nas hipóteses em que o imóvel se encontra localizado em APPs significaria, antes de tudo, enriquecimento sem causa, vedado pelo ordenamento jurídico.

De acordo com Ingo Wolfgang Sarlet e Tiago Fensterseifer, o STJ já consolidou o entendimento de ser impossível o pagamento de indenização ao proprietário de imóvel que tem o seu exercício limitado em razão do enquadramento da sua área em algum regime de proteção ambiental: 


\begin{abstract}
A função ambiental da propriedade e os correspondentes deveres fundamentais atribuídas ao seu titular tem encontrado [...] guarida na jurisprudência do Superior Tribunal de Justiça, que consolidou entendimento no sentido de ser incabível o pagamento de indenização ao proprietário de imóvel que tem o seu exercício limitado em razão do enquadramento da sua área em algum regime de proteção ambiental (notadamente, no caso de área de preservação permanente, reserva legal ou mesmo de unidade de conservação). Em outras palavras, o STJ compreende que as limitações sofridas pelo titular do direito de propriedade (e possuidor) em relação a não utilização econômica e manutenção da reserva legal e da área de preservação permanente estão amparadas pela obrigação que o mesmo tem de manter o equilíbrio ecológico da área sobre o seu domínio, de modo que não lhe cabe reivindicar qualquer indenização decorrente da limitação sofrida no exercício do seu direito. (SARLET e FENSTERSEIFER, 2014, p. 110-111)
\end{abstract}

A título exemplificativo, temos o Recurso Especial $\mathrm{n}^{0}$ 1.090.607-SC, julgado em 2015 pela Primeira Turma do Superior Tribunal de Justiça, que entendeu não ser possível nas demandas expropriatórias a indenização da cobertura vegetal componente de APP. Vejamos a ementa do julgado:

ADMINISTRATIVO. RECURSO ESPECIAL. DESAPROPRIAÇÃO. IMPOSSIBILIDADE DE INDENIZAÇÃO DA COBERTURA VEGETAL LOCALIZADA EM ÁREA DE PRESERVAÇÃO PERMANENTE. PRECEDENTES.

1. Nas demandas expropriatórias, é incabível a indenizacão da cobertura vegetal componente de área de preservacão permanente.

2. Recurso especial provido. ${ }^{10}$ (grifou-se e destacou-se)

Ao longo de seu voto, o Ministro Relator, Sérgio Kukina, sustentou a tese de que os imóveis inseridos em Áreas de Preservação Permanente não possuem qualidade para o recebimento de indenização em caso de expropriação, pois tais áreas não são passíveis de exploração econômica:

10 STJ - Recurso Especial no 1.090.607-SC, Relator: Ministro SÉRGIO KUKINA, Data de Julgamento: 03/02/2015, PRIMEIRA TURMA, Data de Publicação: DJe 11/02/2015. 
Partindo-se da compreensão de que o conceito de indenização pressupõe a existência de um decréscimo patrimonial, não é possível vislumbrar a possibilidade de se compensar a cobertura vegetal que não poderia ser explorada economicamente pelo proprietário do imóvel, porquanto localizada em área de preservação permanente.

$[\ldots]$

Em razão disso, não há como afastar, na espécie, a remansosa jurisprudência desta Corte a respeito da impossibilidade de se indenizar, nas demandas expropriatórias, a cobertura vegetal situada em área de preservação permanente. (SARLET e FENSTERSEIFER, 2014, p. 110-111)

Contudo, interessante mencionar que ao longo do voto, o Ministro Relator reconheceu que a mesma Turma do STJ já havia decidido em outra oportunidade ser cabível a indenização ao particular que possui imóvel situado em APP, desde que os recursos da área em que o imóvel se encontra fossem futuramente de algum modo utilizados economicamente pelo ente expropriante.

Ocorre que, no caso do Recurso Especial no 1.090.607-SC, o Ministro afirmou que não restou comprovado eventual aproveitamento econômico da cobertura vegetal pela entidade expropriante, razão pela qual afastou a indenização pretendida pelo particular.

Outro julgado interessante é o Recurso Especial n 848.577-AC, de relatoria do Ministro Mauro Campbell Marques, que entendeu não ser cabível o direito à indenização, sob o argumento de que o imóvel em litígio já estava limitado para a exploração, pois encontrava-se em áreas de preservação ambiental.

Vejamos a ementa do julgado:

ADMINISTRATIVO E PROCESSUAL CIVIL. DESAPROPRIAÇÃO INDIRETA. COBERTURA VEGETAL. INDENIZAÇÃO EM SEPARADO. ÁREA DE PRESERVAÇÃO AMBIENTAL. IMPOSSIBILIDADE. ALEGADA VIOLAÇÃO DO DISPOSTO NOS ARTIGOS 45 DA LEI 9.985/2000 E 15-B DO DECRETO-LEI № 3.365/41. AUSÊNCIA DE PREQUESTIONAMENTO. ENUNCIADO SUMULAR N. 211/STJ. INCIDÊNCIA. JUROS COMPENSATÓRIOS. IMÓVEL IMPRODUTIVO. IRRELEVÂNCIA. HONORÁRIOS ADVOCATÍCIOS. ARTIGO 27, § 1음 DO DECRETO-LEI 3.365/41. LIMITAÇÃO DE 5\% FIXADO PELO TRF DA $1^{\text {a }}$ REGIÃO. REVISÃO 
DE CRITÉRIOS. IMPOSSIBILIDADE. ENUNCIADO SUMULAR № 7/STJ.

1. Acerca da indenização em separado da cobertura vegetal do imóvel, se verifica no caso em questão que região expropriada está situada na Reserva Extrativista Chico Mendes, no Estado do Acre. A referida reserva foi criada pelo Decreto Estadual 99.144/90 e é área de preservação permanente, declarada de interesse ecológico e social. Ademais, o imóvel em litígio já se encontrava limitado em decorrência do Código Florestal, razão porque, considerando a restrição imposta pelo Código Florestal para a exploracão de áreas de preservação ambiental, inclusive as reservas extrativistas, entendo como não cabível o direito à indenização em conjunto da cobertura florestal, uma vez que esta somente se revelaria devida caso demonstrado o efetivo prejuízo decorrente da criação da Reserva Extrativista Chico Mendes. Ressalte-se, por oportuno, que tal exploração econômica jamais ocorreu, conforme se pode extrair dos autos.

2. Portanto, a concessão de indenizacão nas hipóteses de imóvel situado em área de preservacão ambiental, em que seria impossível a exploracão econômica lícita da área, significaria, antes de tudo, enriquecimento sem causa, sabidamente vedado pelo ordenamento jurídico pátrio. [... $]^{11}$ (grifou-se e destacou-se)

O Ministro Herman Benjamin, ao comentar em artigo acadêmico sobre as limitações internas ao direito de propriedade com relação às Áreas de Preservação Permanente, defende que "constituem um 'ônus indissociável' da titularidade, e que deve ser suportado por seu titular". (BENJAMIN, 1997, p. 20)

Assim, a limitação sofrida pelo titular do direito mostra-se razoável e proporcional, não alcançando o núcleo essencial do direito de propriedade. (SARLET e FENSTERSEIFER, 2014, p. 111)

Como se vê, para essa corrente a criação de Área de Preservação Permanente gera mera limitação administrativa de natureza geral, cujo objetivo é a observância da função social da propriedade, razão pela qual não seria possível falar em direto à indenização.

\section{CONCLUSÃO}

11 STJ - Recurso Especial o 848.577-AC, Relator: Ministro MAURO CAMPBELL MARQUES, Data de Julgamento: 10/08/2010, SEGUNDA TURMA, Data de Publicação: DJe 10/09/2010. 
Como se viu ao longo do trabalho, tanto a doutrina quanto a jurisprudência não são pacíficas acerca da possibilidade de indenização aos proprietários de imóveis situados em Áreas de Preservação Permanente.

As APPs possuem natureza de limitações administrativas, ou seja, são medidas de caráter geral, gratuita, unilateral e de ordem pública que ocasionam a distribuição do sacrifício imposto pela limitação a todos os cidadãos. Assim, em regra, não implicam no direito de indenização àqueles atingidos pelo gravame.

Ocorre que, há quem entenda que as limitações administrativas, quando vedam o uso, gozo e livre disposição da propriedade, desnaturam-se conceitualmente, materializando verdadeira desapropriação e, diante desse cenário, o Estado não está exonerado da obrigação de indenizar os proprietários cujos imóveis venham a ser afetados em sua potencialidade econômica.

Por outro lado, há também quem sustente não ser cabível a indenização a esses proprietários, sob a justificativa de que jamais seria possível a exploração econômica do imóvel situado em Áreas de Preservação Permanente, razão pela qual não há como se compensar a cobertura vegetal que não poderia ser explorada economicamente, de tal modo que a indenização acabaria gerando enriquecimento ilícito.

\section{REFERÊNCIAS}

ANTUNES, Paulo de Bessa. Direito ambiental. $7^{\text {a }}$ ed. Rio de Janeiro: Lumen Juris, 2005.

BENJAMIN, Antônio Herman. Reflexões sobre a hipertrofia do direito de propriedade na tutela da reserva legal e das áreas de preservação permanente. In Anais do $2^{\circ}$ Congresso Internacional de Direito Ambiental. São Paulo: Imesp, 1997.

BRASIL. Ministério do Meio Ambiente (MMA). Áreas de Preservação Permanente Urbana. Disponível em: <http://www.mma.gov.br/cidades-sustentaveis/areas-verdesurbanas/\%C3\%A1reas-de-prote\%C3\%A7\%C3\%A3o-permanente>. Acesso em: 09 mai. 2017. 
Constituição da República Federativa do Brasil de 1988. Diário Oficial da República Federativa do Brasil, Brasília, DF, 05 out. 1988. Disponível em: <http://www.planalto.gov.br/ccivil_03/constituicao/constituicaocompilado.htm>. Acesso em: 08 mai. 2017.

Lei no 12.651, de 25 de maio de 2012. Dispõe sobre a proteção da vegetação nativa e dá outras providências. Diário Oficial da República Federativa do Brasil, Brasília, DF, 28 mai. 2012. Disponível em: <http://www.planalto.gov.br/ccivil_03/_ato2011-2014/2012/lei/l12651.htm>. Acesso em: 08 mai. 2017.

. Lei no 6.938, de 31 de agosto de 1981. Dispõe sobre a Política Nacional do Meio Ambiente, seus fins e mecanismos de formulação e aplicação, e dá outras providências. Diário Oficial da República Federativa do Brasil, Brasília, DF, 02 set. 1981. Disponível em: < http://www.planalto.gov.br/ccivil_03/leis/L6938.htm>. Acesso em: 08 mai. 2017.

.SUPREMO TRIBUNAL FEDERAL - Agravo Regimental no Recurso Extraordinário no 290.950-SP, Relator: Ministro DIAS TOFFOLI, Data de Julgamento: 04/11/2014, PRIMEIRA TURMA, Data de Publicação: DJe 02/02/2015.

Recurso Extraordinário no 134.297-SP, Relator: Ministro CELSO DE MELLO, Data de Julgamento: 02/09/1995, PRIMEIRA TURMA, Data de Publicação: DJ 22/09/1995.

SUPERIOR TRIBUNAL DE JUSTIÇA Recurso Especial no 848.577-AC, Relator: Ministro MAURO CAMPBELL MARQUES, Data de Julgamento: 10/08/2010, SEGUNDA TURMA, Data de Publicação: DJe 10/09/2010.

.Recurso Especial no 1.090.607-SC, Relator: Ministro SÉRGIO KUKINA, Data de Julgamento: 03/02/2015, PRIMEIRA TURMA, Data de Publicação: DJe 11/02/2015.

CARVALHO FILHO, José dos Santos. Manual de direito administrativo. $25^{\mathrm{a}}$ ed. São Paulo: Atlas, 2012.

DI PIETRO, Maria Sylvia Zanella. Direito administrativo. 19a ed. São Paulo: Atlas, 2006.

HEINE, Juliano. Limitações administrativas e o conteúdo econômico da propriedade: uma desapropriação à brasileira. Rio de Janeiro: Revista de Direito Administrativo, Vol. 260, p. 133-181, Mai. - ago. 2012, p. 172-173. Disponível em: $<$ http://bibliotecadigital.fgv.br/ojs/index.php/rda/article/viewFile/8833/7626>. Acesso em: 09 mai. 2017. 
LEMBO, Claudio. A Pessoa: seus direitos. São Paulo: Manole, 2007.

MACHADO, Paulo Affonso Leme. Inovações na legislação ambiental brasileira: a proteção das florestas. Belo Horizonte: Revista Veredas do Direito, Vol.10, n. 19, p.11-21, Jan. - Jun. 2013.

MEIRELLES, Hely Lopes. Direito administrativo brasileiro. 26 ed. São Paulo: Malheiros, 2001.

RAMOS, Lívia Nogueira. Desapropriação Direta e Indireta. Disponível em: $<$ http://www.pesquisedireito.com/desapropr_dir_indir.htm>. Acesso em: 09 mai. 2017.

SALLES, José Carlos de Moraes. A desapropriação à luz da doutrina e da jurisprudência. 5ª ed. São Paulo: Revista dos Tribunais, 2006.

SARLET, Ingo Wolfgang; FENSTERSEIFER, Tiago. Princípios do direito ambiental. São Paulo: Saraiva, 2014.

SCHAFFER, Wigold Bertoldo et al. Áreas de Preservação Permanente e Unidades de Conservação \& Áreas de Risco. O que uma coisa tem a ver com a outra? Relatório de Inspeção da área atingida pela tragédia das chuvas na Região Serrana do Rio de Janeiro. Brasília: Ministério do Meio Ambiente, 2011.

SLAIB FILHO, Nagib. Anotações à Constituição de 1988. Rio de Janeiro: Forense, 1989.

SOARES, Vivian Bacaro Nunes; PADILHA, Norma Sueli. A função sócio-ambiental como fundamento jurídico principiológico da propriedade. Anais do XVIII Congresso Nacional do Conpedi, 2009. Disponível em: <http://www.publicadireito.com.br/conpedi/manaus/arquivos/Anais/sao_paulo/2512.p df>. Acesso em: 09 mai. 2017. 